\title{
Tensile Strength of the Brittle Materials, Probabilistic or Deterministic Approach?
}

\author{
J. Jeong,, H. Adib-Ramezani, ${ }^{\text {b }}$ and G. Pluvinagea \\ a Laboratoire de Fiabilité Mécanique, Université de Metz, France \\ b École Polytechnique de 1'Université d'Orléans, France
}

УЛК 539.4

\section{Прочность при растяжении хрупких материалов: вероятностный или детерминистический подход?}

\author{
Ж. Жеонг ${ }^{\mathrm{a}}$, Х. Адиб-Рамезани ${ }^{\sigma}$, Г. Плювинаж ${ }^{\mathrm{a}}$ \\ a Лаборатория механической надежности, Университет г. Метц, Франция \\ ${ }^{\sigma}$ Политехнический институт, Университет г. Орлеан, Франция
}

\begin{abstract}
Для различных скоростей нагружения оиенена локализация активированньхх дефектов в стеклянном образце в виде модифицированного бразильского диска по сравненио со стандартным сферическим образиом. Геометрия образиа может оказывать суиественное влияние на механическое поведение материала, особенно это относится к очень чувствительныл к распределению дефектов хрупким материалам. Для анализа полученньх резульmатов используется статистический подход Вейбулла. С использованием универсальной испьтпательной маиины "Ннстрон” и захватов Гопкинсона для сэсатия реализовань вьлсокие и низкие скорости нагружения образиов в виде модифииированного бразильского диска из высскопрочного стекла. Полученные экспериментальные результатьл сравнивали с распределением Вейбулда с точки зрения рассеяния прочностных характеристик. С помоиью метода конечных элементов рассчитано поле напряжений в образиах указанного типа, что позволило более детально изучить хрупкий макромеханический механизм разруиения. Установлено, что при статических испьтаниях сферических стеклянных образиов возникают контактные напряжения, приводящие к активации дефектов в рабочей части образцов. $B$ образиах типа модифицированного бразильского диска не наблюдалось активации дефектов ни при статическом, ни при динамическом нагружении. Для образиов различой геометрической формы и вида приложения нагрузки реколендуется использовать вероятностный подход, например подход Вейбулла, поскольку контактные напряжения в хрупких материалах вызывают активацию дефектов, расположение которьх, в свою очередь, зависит от геометрии и вида нагружения образца
\end{abstract}

Ключевые слова: хрупкие материалы, разброс прочностных характеристик, локализация дефекта, распределение Вейбулла.

Introduction. The brittle materials, especially the glass materials show the perfect elastic behavior until the failure occurs and present a substantial scatter resistance value under applied loadings contrary to the ductile ones. The absence of crystal network and pre-existing microdefects provide the sensitivity concept based on stress concentration around the defects [1]. It shows less resistance value C J. JEONG, H. ADIB-RAMEZANI, G. PLUVINAGE, 2006 100 
than the theoretical atomic cohesion and also unpredictable strength value. Because of those reasons the probabilistic approach as Weibull's distribution including two parameters has become a practical method to assess the variation of resistance for the brittle materials [2, 3]. The Weibull's modulus for dynamic loading application is frequently utilized. Recently, the study concerning the strength of the brittle materials under high loading rate has become an important subject regarding to several industrial applications as foreign object impact and thermal shock problem. It is well known that the brittle materials exhibit the strength increase under high loading applications [4-7]. The advanced study was carried out to demonstrate more strength variation sensitivity reason under the high loading application for the brittle materials than the ductile materials via Weibull's modulus [8].

The dynamic fracture on the brittle materials leads to the particular failure mechanism like a multi-activation of the defects and the failure of the whole of material not simple fracture from a critical defect. These fracture mechanisms have been interpreted as a damage phenomenon in the literature [5]. Some works show that the mentioned dynamic brittle fracture mechanism provides less scatter value than the static's one and so, the deterministic approach was proposed in [4]. According to their works, the brittle material exhibits one strength value if it is subjected to the high loading rate. However, other studies indicate greater scatter value for high velocity loading than the static ones for the brittle materials $[7,8]$. Considering these controversial results which have been reported in the literature, which include probabilistic and/or deterministic approaches according to the various loading rate, in this paper it is attempted to clarify and simplify this diverge phenomenon by means of the fracture pattern mechanism analysis due to the activated defects position, contact problem on the specimen geometry and the loading type on the brittle materials. For these reasons, the application of the quasi-static and high loading rates on lead glass material is performed and the experimental results are analyzed via the Weibull's distribution and localization of the activated defects on the specimen geometry and loading type.

1. Quasi-Static Compression of the Glass Material Specimen. Firstly the quasi-static case is considered. The experiments on lead glass material disk under lateral compression are performed to investigate the position of crack initiation and the scatter in maximum failure loads based on the Weibull's distribution.

1.1. Experiments. The uniaxial compression Brazilian test is commonly used on the brittle materials to apply the compression at top of the disk specimen. This loading condition can provide the indirect tensile strength in direction of the median plane. In the experiment, the Brazilian Disk consists of one small central hole ( $2 \mathrm{~mm}$ diameter) on the outer disk of which diameter and thickness are $20 \mathrm{~mm}$ and $6 \mathrm{~mm}$, respectively. That geometry is taken to induce the stress concentration around the notch tip. Hence, this Modified Brazilian Disk (MBD) lead glass material will be broken by the notch tip crack concept. All specimens have been manufactured by the molding technique of injecting the hot crystal liquid (more than $800^{\circ} \mathrm{C}$ ) in prepared shape. This method permits to avoid some undesirable defects on the surface of specimen during manufacturing process. The applied lead glass specimen in the experiment has the mechanical properties in Table 1. 
J. Jeong, H. Adib-Ramezani, and G. Plwinage

$\mathrm{T}$ a b 1 e 1

Mechanical Properties of Applied Lead Glass Material

\begin{tabular}{|c|c|c|}
\hline Young's modulus $E, \mathrm{GPa}$ & Poisson's ratio $v$ & Density $\rho, \mathrm{kg} / \mathrm{m}^{3}$ \\
\hline 59 & 0.218 & 4350 \\
\hline
\end{tabular}

The compressed MBD lead glass is placed between two semi-cylinder aluminum anvils made of adjustable specimen form. This configuration of anvils prevents the maximum pressure presence at the contact point during the compression application process. The compression tests were performed using Instron 4505 servo-hydraulic testing machine. The stroke velocity was controlled to have $10^{-5} \mathrm{~mm}$ displacement per minute. When failure occurs, the load is instantaneously reduced and the test is stopped. The ultimate strength corresponds to the maximum load recorded during the test. Many researches have been carried out on the spherical glass specimen under the compression to determinate the defects initiation. In the previous works it was reported that failure occurred on the surface contact zone $[9,10]$. In the experiment of this paper, the MBD specimen is made of commercial lead glass, so called crystal glass. This specimen geometry allows us to compare the role of the defects on the surface under inducing indirect and compressive stress with spherical glass specimen form.

1.2. Results. When the failure occurs, the ultimate load is recorded and the maximum stress can be calculated by Eq. (1)

$$
\sigma_{r}=\frac{2 K_{t} P}{\pi L D}
$$

where $\sigma_{r}, K_{t}, P, L$, and $D$ are the maximum stress, stress concentration factor, failure load, thickness, and diameter, respectively [11]. The value of stress concentration factor for MBD specimen is presented in Fig 1.

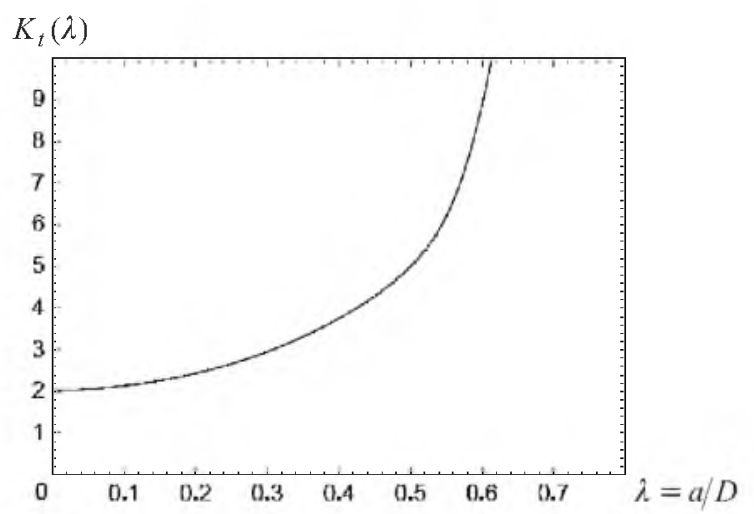

Fig. 1. The stress concentration factor for MBD specimen versus ratio of inside diameter $(a)$ and outside diameter $(D)[11]$.

The main result is summarized and compared with the soda-lime glass of which test is performed on the same MBD specimen (Table 2). A photograph of the fragmentation after test is shown in Fig. 2. 
Tensile Strength of the Brittle Materials...

$\mathrm{T}$ a b 1 e 2

Statistical Tensile Strength Results for Glass Materials

\begin{tabular}{|c|c|c|}
\hline Glass material & Mean value (MPa) & Standard deviation (MPa) \\
\hline Lead glass & 46.70 & 8.60 \\
\hline Soda-lime glass [12] & 96.30 & 13.66 \\
\hline
\end{tabular}

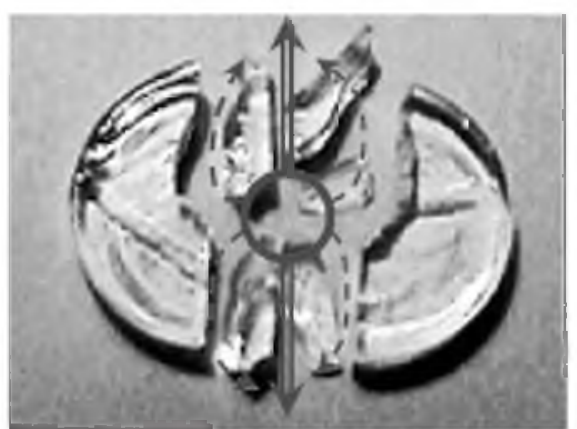

Fig. 2. General mechanism of fragmentation for MBD lead glass specimen subjected to the lateral compression including quasi-static loading.

In general, all MBD lead glass specimens are split into six pieces at the small hole (ring appeared in Fig. 2) and the cracks very rapidly propagate (not visible by naked eye) toward both direction of top and bottom of the specimen (straight and dashed lines in Fig. 2). The fragmentation provokes crash failure. This mechanism of fragmentation is entirely different and compared with the spherical glass specimen which is comminuted and reduced into very thin powder $[9,10]$. The stress distribution of MBD specimen and high stress concentration near the central hole are needed to be investigated via numerical simulation methods and corresponding results provide more comprehensive understanding of the macro level fracture mechanism view. The mesh is made only in a quarter of MBD specimen because of the symmetric assumptions. The detail view around the central hole is represented in Fig. 3b. The static loading is considered for the finite element method (FEM) analysis. The bottom of geometry is fixed completely and the concentrated force equivalent to failure's one is applied at the top of specimen. The simulation result using the finite element implies that the indirect tensile stress or opening stress is distributed on the vertical direction toward the applied static loading and the stress in $x$ direction $\left(\sigma_{x x}\right)$ is located near the center of hole which attains more than $41 \mathrm{MPa}$ under an average compressive failure force $(1,25 \mathrm{kN})$ (Fig. 4).

Consequently, the cracks propagate on the vertical direction from the central hole. This primarily results in a fracture of specimen in median plane. The second crack is placed in $45^{\circ}$ direction (diagonal direction) and it propagates toward the top of specimen and creates a second fracture. The FEM results enable to explain the mentioned mechanism of fracture in MBD specimen (Figs. 4 and 5). The high compressive stress near bottom and top of MBD specimen can be observed. The aforementioned positions represent the compressive stress more than $260 \mathrm{MPa}$ based on FEM results. The FEM analysis accords with Hertzian cone crack (ring and dashed line in Fig. 4) morphology. In spite of the fact that the contact zones 
are locally damaged during the quasi-static test process, the emphasized zones never change the failure mechanism and mechanical resistance due to critical defect inactivation.
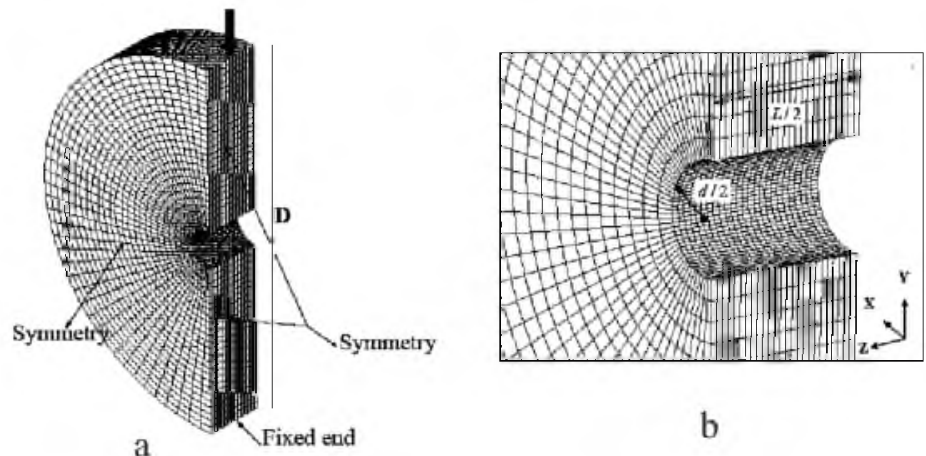

$\mathrm{b}$

Fig. 3. Mesh density for a quarter of model (a) and detailed mesh density (b) around the central hole (d $=2 \mathrm{~mm}, L=6 \mathrm{~mm}$, and $D=20 \mathrm{~mm}$ ).

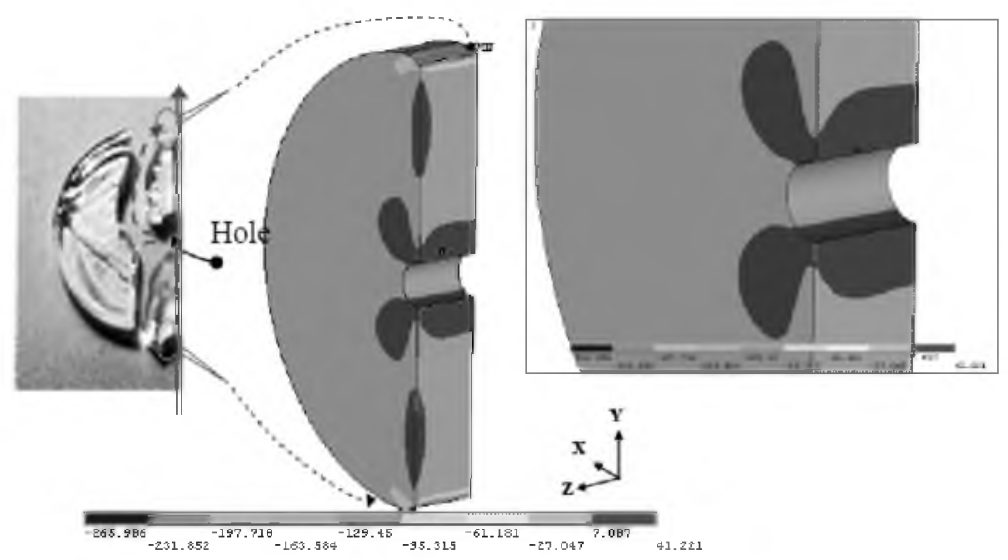

Fig. 4. MBD specimen including highlighted crack directions and stress distribution in $x$ direction (in $\mathrm{MPa}$ ) based on the finite element method outcome indicating high indirect tensile stress around central hole.

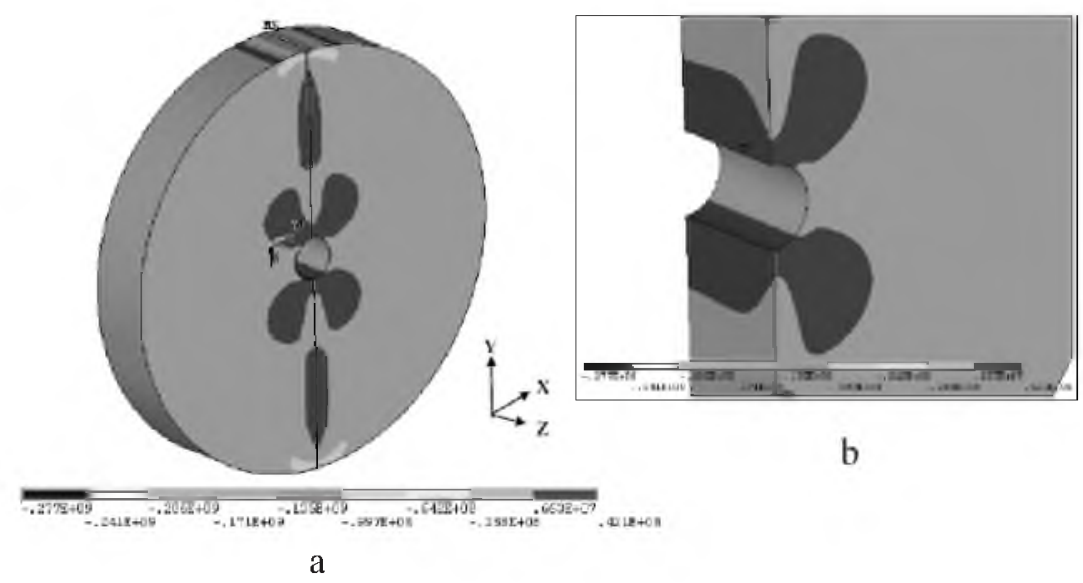

Fig. 5. One half symmetric FEM model (a) indicating stress in $x$ direction (in Pa) and one fourth detail view around considered hole (b). 


\section{Probabilistic Analysis.}

2.1. Weibull's Distribution. According to the Freudental's proposition [3], the probability of occurrence of a critical defect decreases at small volume while it can increase at the large volume as following:

$$
F(V)=1-\exp \left[-\left(\frac{V}{V_{0}}\right)\right],
$$

where $V$ is the mean volume occupied by a defect, $V$ is the volume, and $F(V)$ is the probability of an occurrence of critical defect in the volume.

The Griffith's experimental tests of strength of material for glass fiber diameter effect can be explained by the above relationship (Eq. (2)). Due to the aforementioned probabilistic idea, the concept of volume and the consideration of the quantity of defect have also become as an essential point of view to consider the probabilistic approach. Considering Eq. (2), Weibull proposed the probability of failure replacing the applied stress in the volume occupied by a defect:

$$
P_{r}(\sigma)=1-\exp \left[-V\left(\frac{\sigma}{\sigma_{0}}\right)^{\beta}\right],
$$

where $P_{r}(\sigma)$ is the failure probability, $\sigma_{0}$ is called a scale parameter which is proportional to the mean stress, and $\beta$ is Weibull's modulus which deals with the divergence in outcomes.

The volume size effect on probability of failure in the Weibull's distribution should be taken into account. The above relationship indicates a two parameter the Weibull's distribution, which are frequently used. The Weibull's modulus $\beta$ in Eq. (3) for this distribution can be extracted using simple rank regression analysis from the density function as follows:

$$
\ln \left[\ln \left(\frac{1}{1-P_{r}}\right)\right]=\beta \ln (\sigma)+\beta \ln \left(\frac{1}{\beta}\right)
$$

and

$$
P_{r}=\frac{i}{n+1},
$$

where $i$ is the specimen's number and $n$ is the total number of specimens.

The static strength experimental results are presented via rank regression analysis (Eq. (5)) in Fig. 6. The Weibull's modulus corresponding to 5.7964 is extracted in this paper. There is another method to obtain the Weibull's modulus. That is the coefficient of variation $(C V)$ application.

2.2. Coefficient of Variation in the Analysis of the Weibull's Distribution. The method of coefficient of variation $(\mathrm{CV})$ for the statistical distribution of material properties including the ultimate strength is a very feasible statistical 
way. The method can be defined as the ratio of the standard deviation to the mean [13] as below

$$
C V=\frac{\sigma_{s}}{\mu_{s}}
$$

where $\sigma_{s}$ and $\mu_{s}$ are standard deviation and means values, respectively.

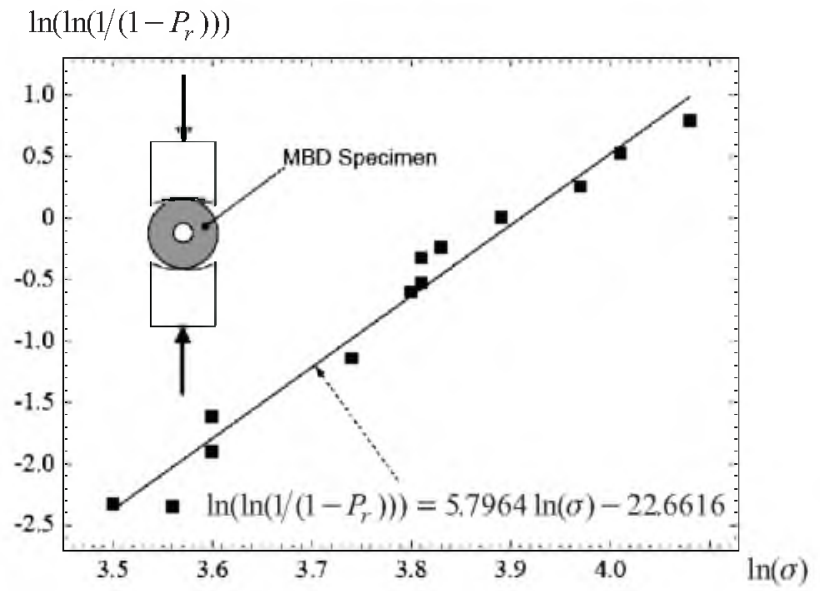

Fig. 6. Rank regression analysis for MBD lead glass: the line corresponds to the Eq. (4) and tangent $\beta$ represents the scatter value (5.7964) including correlation coefficient $\left(R^{2}=0.975\right)$.

The complicated functional relationship may be transformed into a simple form by using the concept of coefficient of variation. It greatly simplifies the calculation of statistical parameters and the obtained results are very close to the original functional relationship. The $C V$ can be determined for the most common distribution as exponential, log-normal and Weibull's distribution. In this paper, two parameters Weibull's distribution and $C V$ concept are employed. The probability of Weibull's density function can be written as

$$
f(\sigma)=\frac{\beta}{\sigma_{0}}\left(\frac{\sigma}{\sigma_{0}}\right)^{\beta-1} \exp \left[-\left(\frac{\sigma}{\sigma_{0}}\right)^{\beta}\right] .
$$

From the definition of the mean and the standard deviation values for each probability density function, we can deduce the mean and the standard deviation value of the Weibull's distribution as follows:

$$
\begin{gathered}
\mu_{s}=\sigma_{0} \Gamma\left(1+\frac{1}{\beta}\right), \\
\sigma_{s}=\sigma_{0}\left\{\Gamma\left(1+\frac{2}{\beta}\right)-\left[\Gamma\left(1+\frac{1}{\beta}\right)\right]^{2}\right\},
\end{gathered}
$$




$$
C V=\left[\frac{\Gamma(1+(2 / \beta))}{(\Gamma(1+(1 / \beta)))^{2}}-1\right]^{1 / 2} \approx \beta^{-0.93} \quad \text { for } \quad 1 \leq \beta \leq 50 \text {, }
$$

where $\Gamma$ is gamma function.

The above relationship (Eq. (10)) allows to evaluate the Weibull's modulus value using the coefficient of variation. Therefore we can examine the scatter value in the literature using $C V$ to compare our results.

2.3. Example. X. Brajer et al. [9] performed the compressive test on the spherical glass specimen with various diameters from $2 \mathrm{~mm}$ to $8 \mathrm{~mm}$ in order to obtain the relationship between the maximum loading and different diameter. The spherical glass specimen has been compressed between two steel planar anvils and aluminum shim insertion. Their results are shown as solid line in Fig. 7, where it can be observed that larger sphere diameters tend to have greater mean load value. This is contrary to the expressed relations in Eqs. (2) and (3) (Freudental-Weibull's failure probability approach) which present asymptotic variation of failure probability versus volume augmentation. Furthermore, the aluminum shim insertion under the steel plate anvil considerably increases the strength.

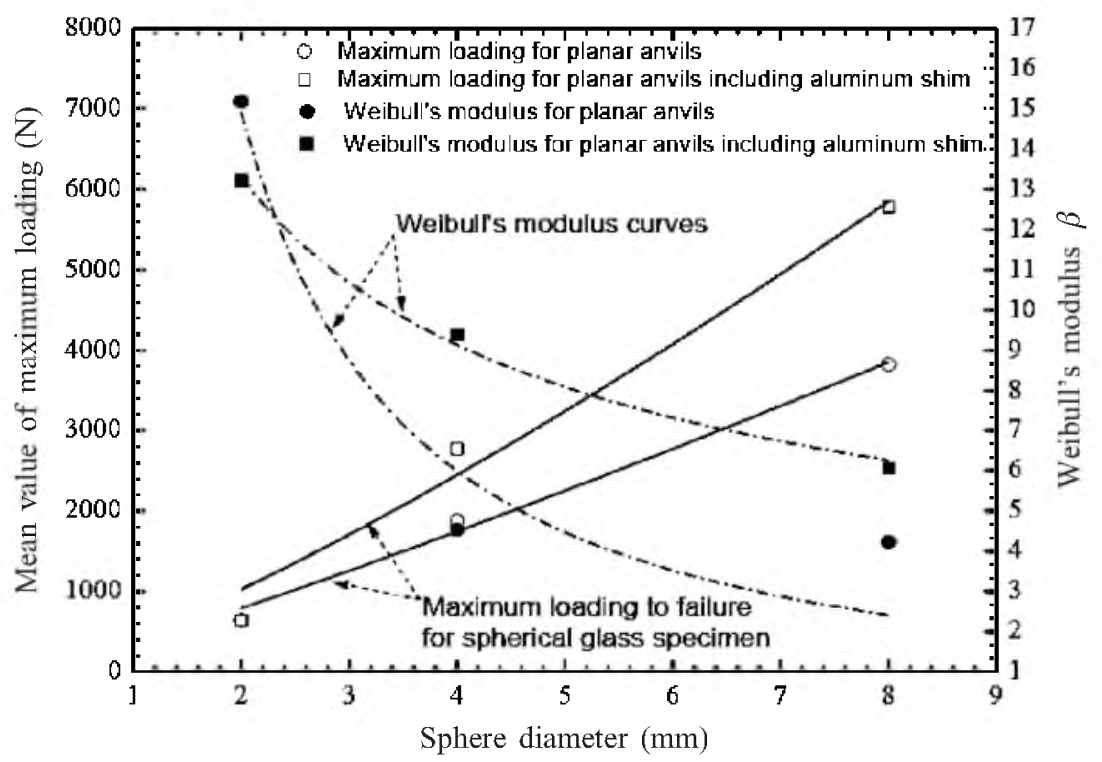

Fig. 7. Mean failure loading values and Weibull's modulus as a function of diameters of spherical glass specimen with and without aluminum shim insertion.

Using the $C V$ in Eq. (10), the Weibull's modulus value $\beta$ is calculated and presented as two dashed lines in Fig. 7. Moreover, the parameters $\beta$, critical stress and affected volume are more sensitive without aluminum shim insertion. This means that added aluminum shim at the bottom and top of tested specimen can reduce the contact problem severity. It is also found that the failure takes place just under the contact surface. The evaluation demonstrates that the spherical glass specimens of small diameter provide less random behavior 
$(\beta>15)$ and low mechanical resistance. To understand and resolve these controversial results, we investigate the contact problem nature in considered spherical specimens which are commonly ignored.

3. Analysis of Contact Problem on Spherical and MBD Specimen under Compressive Loading. In Fig. 8, the selected spherical glass specimens with different diameters including contact considerations are presented for the identical loading $(880 \mathrm{~N})$. The results of finite element method in median plane are focused on using 8-node structural brick element of ABAQUS code. The tensile stress and compressive stress are exhibited under contact condition. The comparison between compressive and tensile zones shows that the contact weight has influence on mechanical resistance of chosen specimens. As a matter of fact, low spherical glass specimen diameter yields severe contact effects and the current effects disturb mechanical resistance nature, i.e., the mechanical resistance of material explicitly depends on induced contact state in specimen. In fact, the spherical experiments are not appropriate test method to evaluate the mechanical resistance of the brittle materials due to highly contact-dependent intrinsic characteristics.

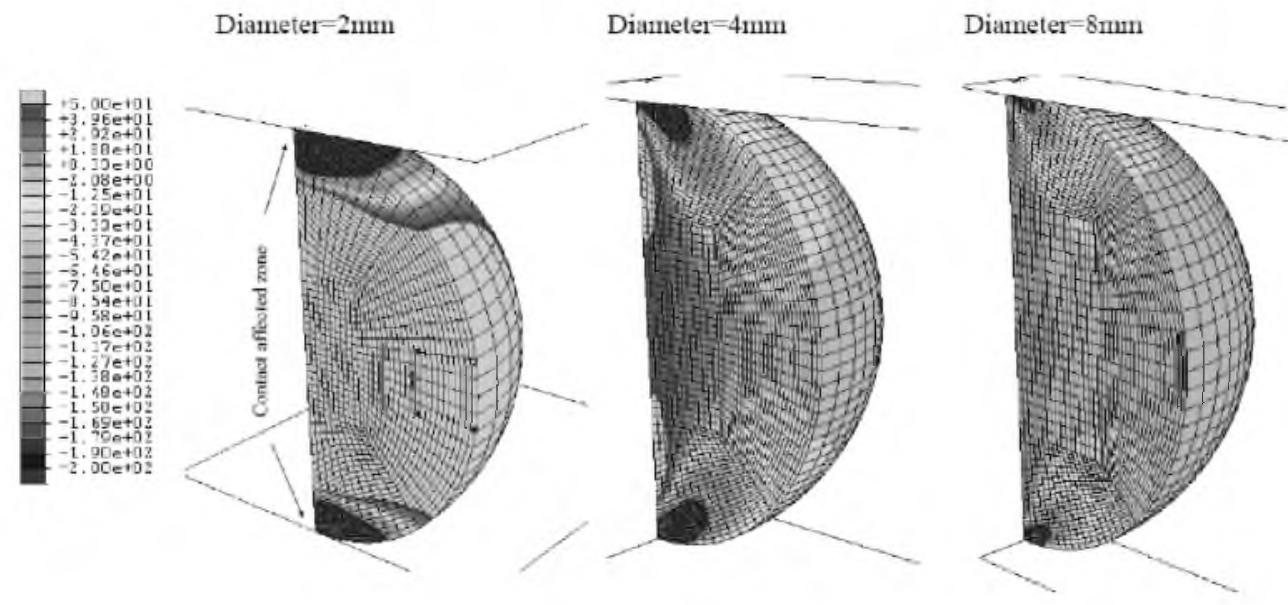

Fig. 8. Contact severity variations for spherical glass specimen with different diameters using stress distribution in loading direction (in MPa) including identical axial force $(880 \mathrm{~N})$ and one-fourth symmetry assumption.

The experimental results reported in [9] and our evaluation $\beta$, indicate that the contact area is increased with the sphere diameter and aluminum shim insertion of which Young's modulus value is smaller than steel's one. Consequently, the pressure amplitude on contact area decreases i.e., the contact pressure has influence upon the real strength of material and its corresponding intrinsic parameter as Weibull's modulus. From the above facts, the following conclusions can be drawn:

- the geometry of specimen can influence both strength of material and also the scatter value;

- the condition of loading and the relative contact problem can manipulate the strength of the brittle materials.

In addition, it is attempted to find out the origin of fracture for MBD specimen by means of optical microscopy $(\mathrm{OM})$ and scanning electric microscope 
(SEM) around the small center hole at which the maximum tensile stress occurs (Fig. 9). The failure mechanism of MBD specimen is very different compared with the spherical glass specimen which is broken into the fin powder. In fact, the failure occurs near the maximum tensile stress point and it is possible to detect a small piece which is lost due to the contact pressure problem just under the point of loading application. This point does not cause the specimen failure. The similar compressive test for MBD soda lime glass specimen has been carried out with different thickness for $5 \mathrm{~mm}$ diameter [12]. The experiment using such a material showed that more fragile fracture happened with greater diameters. This effect of the strength decrease due to larger specimen size has been observed by several authors $[14,15]$ and it is also predicted by certain statistical approaches (Eqs. (2) and (3)).

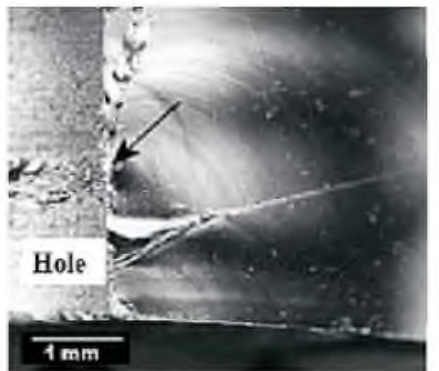

a

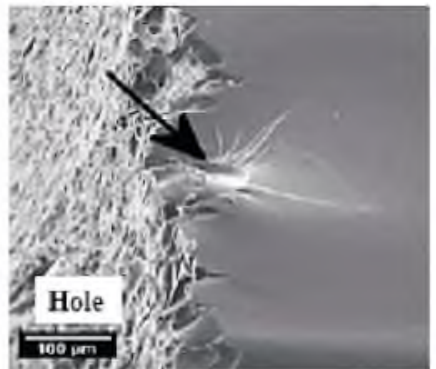

b

Fig. 9. Start position of fracture via OM (a) and detail view of this point via SEM [16] (b).

Moreover, the activated defects are localized not near the contact area at the maximum tensile stress point. Nonetheless, different mechanical behaviors have been observed for the spherical glass specimen in which the fracture always occurs near the contact zone $[9,10]$. This inducing contact problem due to the loading type condition and the specimen geometry can be verified for the dynamic loading application as "edge on impact" or ballistic test. In the next section an experiment of the dynamic loading application via compressive split Hopkinson pressure bars (CSHPB) for MBD lead glass specimen is explained and its result is compared with the edge on impact reported in the literature.

4. Dynamic Loading via CSHPB. In the previous section it was demonstrated that the crack initiation is located not close to the contact zone but adjacent to the central hole where the maximum tensile stress is applied. A similar experiment for dynamic condition via CSHPB is presented in this section. Additionally, the cracking pattern will be examined under this condition test and compared with the edge on impact or ballistic test in which the contact pressure zone is still available as the spherical glass specimen under static loading.

4.1. Experiments and Results. It is well known that the strength of the brittle materials can increase up to two times greater than the static's one under the dynamic loading condition. In addition, this high loading rate yields a damage phenomenon in these materials inducing the different crack pattern relative to the static's one. The compressive split Hopkinson pressure bars test is employed to apply a dynamic loading to MBD specimen. As a matter of fact, the MBD specimen is placed between two bars which are called incident and output bars 
whose lengths are $1100 \mathrm{~mm}$ and $900 \mathrm{~mm}$, respectively (Fig. 10). A striker bar of $500 \mathrm{~mm}$ is launched to apply a perfect impact to the incident bar. Two mounted gauges on output and incident bars are used to record the electric signals which represent the compressive strain and tensile strength of the specimen, respectively.

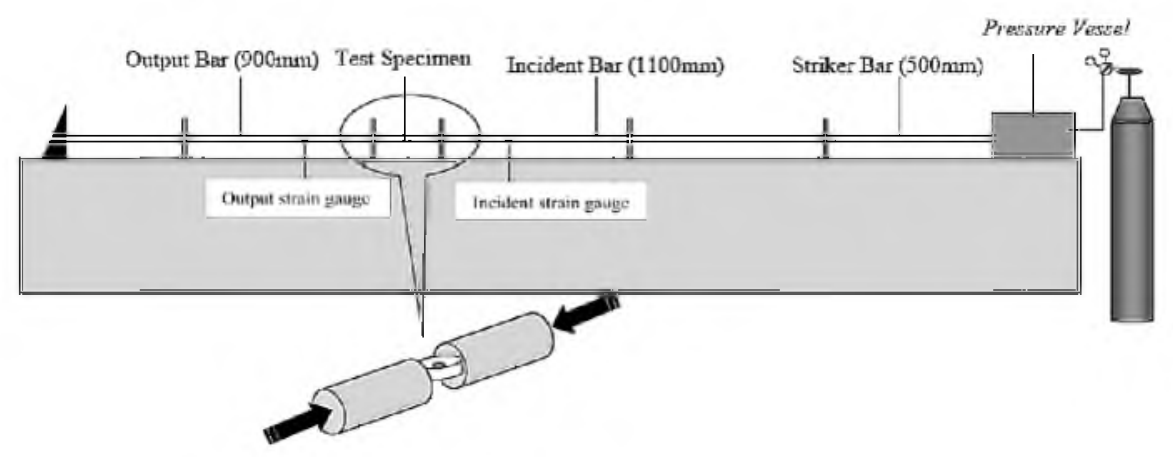

Fig. 10. Compressive split Hopkinson pressure bars general configuration.

The mismatch of acoustic impedance between the metal bars and the crystal specimen causes that the elastic compressive longitudinal wave partially transmits into the specimen and arrives to the output bar. The loading wave amplitude is a function of the velocity of striker bar, the density and celerity of sound in the bar. The flawless impact of bars has a square-shaped pulse of magnitude given by motion equation:

$$
\sigma=\frac{v \rho_{\text {bar }} c}{2}
$$

and duration

$$
T=\frac{2 l}{c},
$$

where the parameters $v, \rho_{b a r}, c$, and $l$ are the impact bar's velocity, density of bar, wave velocity of bar, and bar length, respectively. Assuming that the specimen is in dynamic equilibrium state and it uniformly deforms, the strains in the incident bar are equal to the strain in the output bar and the expression for the average stress on specimen for our case can be written as follows:

$$
\sigma_{a v}(t)=E \frac{D_{\text {bar }}^{2}}{D_{\text {specimen }}^{2}} \varepsilon_{t},
$$

where $\sigma_{a v}, E, D_{b a r}, D_{\text {specimen }}$, and $\varepsilon_{t}(t)$ are average stress, Young's modulus of specimen, diameter of bar, diameter of specimen, and strain amplitude on transmitter bar, respectively.

Assuming nondispersive one-dimensional wave propagation theory, the applied velocity of deformation corresponds to $275 / \mathrm{s}$ in this paper. The obtained stress amplitude due to this applied velocity of deformation assures the dynamic equilibrium theoretical approach that the dynamic fracture time of material must not be less than three times of celerity in this material [17]. 
Tensile Strength of the Brittle Materials...

$\mathrm{T}$ a b 1 e 3

Statistical Results of MBD Lead Glass Tensile Strength

\begin{tabular}{|c|c|c|}
\hline Tensile strength (MPa) & Mean value (MPa) & Standard deviation (MPa) \\
\hline Dynamic test & 93.0 & 21.0 \\
\hline
\end{tabular}

Figure 11 shows a typical dynamic fracture results and in Table 3, there are the measured mean maximum strength and standard deviation values. The experiments demonstrate that the MBD lead glass specimen was broken into several fragmentations on regular fracture pattern without high compressive zone which can be found for the contact problem (Fig. 4). The current dynamic fracture can be elucidated by the simultaneous activation of majority of flaws by compressive pulse stress propagation in specimen body. The fracture mechanism results lead to the augmentation of the strength of material under dynamic loading based on the energy intensity equality described by the area of applied stress and fracture time [5]. Consequently, the fragmentation including damage is proportional to the applied energy intensity. It is supposed that the above fragmentation pattern of MBD specimen can be initiated on a large amount of fragments to be detached along the tensile stress concentration which can be obtained by finite element method (Figs. 4 and 5) during a very short time (the average of failure time is about $50 \mu \mathrm{s}$ for all specimens). Figure 12 illustrates steps of the assumed fragmentation. Firstly, the compressive wave propagation provokes the activation of a large number of microcrack in the meridian plane (Fig. 12a) and then, the diagonal direction (Fig. 12b). Finally, the microcracks appear in the whole specimen (Fig. 12c) and failure happens. Consequently, the fracture pattern is regular around the small hole and propagates on the whole material. The contact Hertzian problem in these failure types can not be detected and the fracture is due to the defects on volume entity not on a surface.

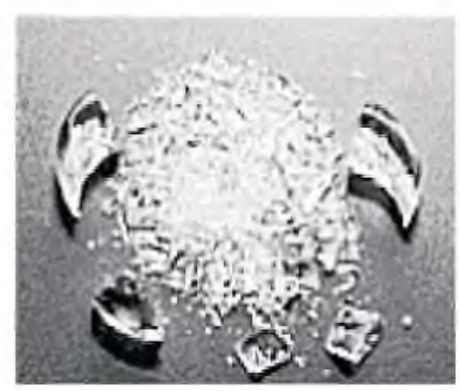

Fig. 11. Dynamic fracture of MBD lead glass specimen
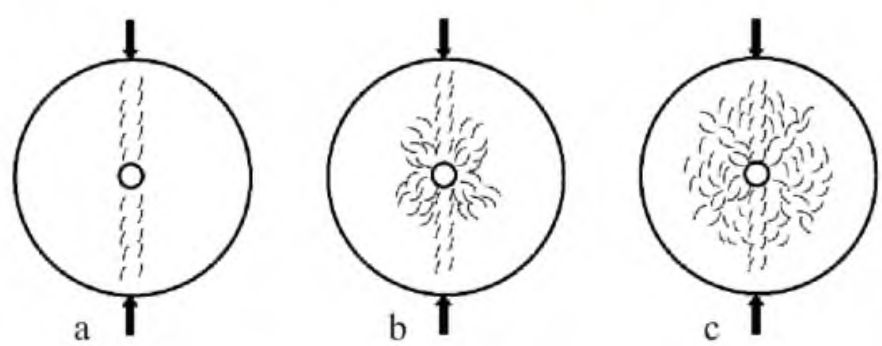

Fig. 12. Schematics of the main configuration of failure for MBD specimen at high velocity impact. 
4.2. Discussion. It has been found that the strength of lead glass material under the dynamic loading instead of static's one increases from 46.7 to $93 \mathrm{MPa}$ and the various scatter levels for two loading conditions are compared using Weibull's distribution in Fig. 13. The Weibull's modulus has been calculated $(\beta=3.6)$ and this value is smaller than the static's one $(\beta=5.79)$.

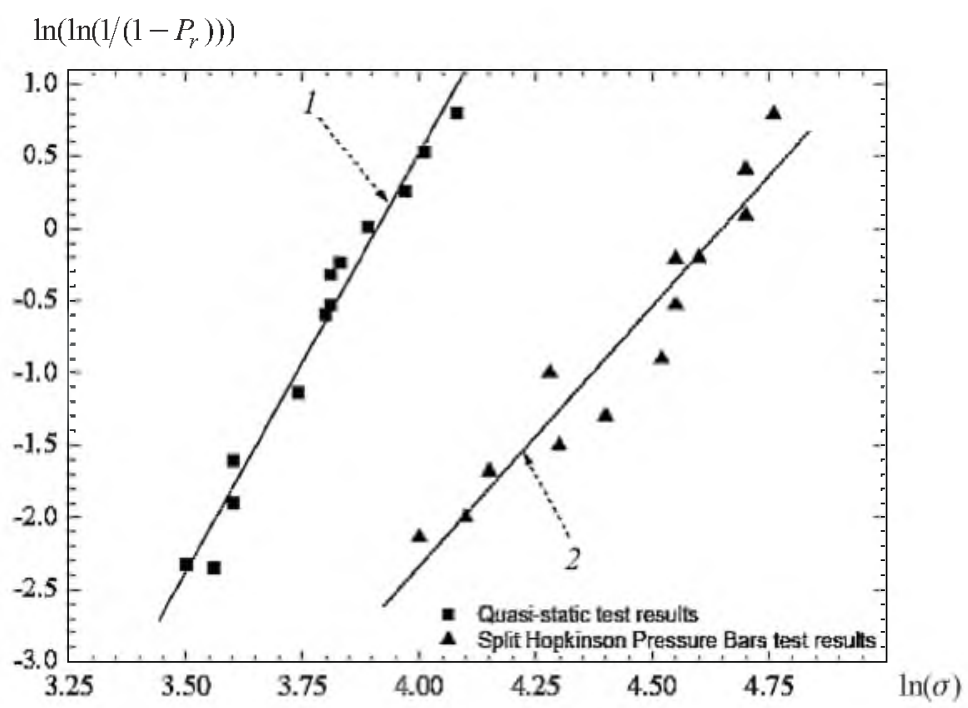

Fig. 13. Weibull's modulus presentation including the static and dynamic loadings: (I) $\ln \left(\ln \left(1 /\left(1-P_{r}\right)\right)\right)=5.7964 \ln (\sigma)-22.6616 ;(2) \ln \left(\ln \left(1 /\left(1-P_{r}\right)\right)\right)=3.6047 \ln (\sigma)-16.7567$.

The above values have the same range as soda lime glass whose range is mostly about $5 \sim 10$. Our experimental results show that the dynamic failure mechanism by regular crack pattern in volume results in a damage phenomenon as fragmentation and also more random strength value. The edge on impact test or ballistic test presents the same damage mechanism which we can detect via CSHPB condition. Figure 14 represents an impact zone (dark zone) by a lead bullet (Fig. 14a) and a steel one (Fig. 14b) on soda lime glass subjected to the ballistic test [9]. From the results reported in [9], the dark zones correspond to the damage ones and this zone in the vicinity of the impact is totally comminuted. The second area illustrates a high density of radial and orthoradial cracks and the propagation of long radial cracks appears in the third zone.

The above fracture mechanism is a typical fracture pattern for all applied specimens under impact loading. The obtained damage severity makes more important the fragmentation for the soda lime glass material subjected to the impact condition and it depends on the velocity of impact [5]. Hence, X. Brajer et al. [9] indicated that the soft bullet (lead bullet) provokes a large damage zone (Fig. 14a) compared with the hard bullet (Fig 14b). It should be recalled that the soft bullet was launched with less velocity $(430 \mathrm{~m} / \mathrm{s}$ ) than the hard bullet (steel bullet, $820 \mathrm{~m} / \mathrm{s}$ ). The authors observed a Rayleigh's surface wave on the contact zone by the soft bullet and concluded that the activated defects under the impact are positioned on the surface of specimen not in volume like the spherical glass specimen under the static loading. 
Tensile Strength of the Brittle Materials..

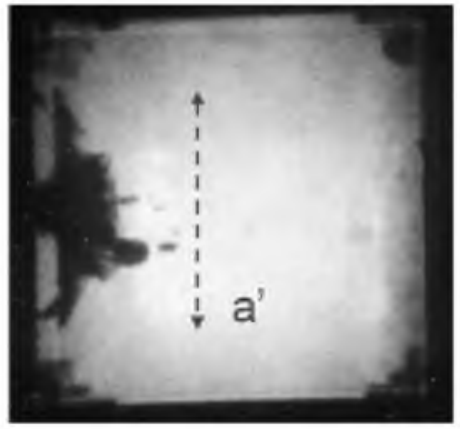

a

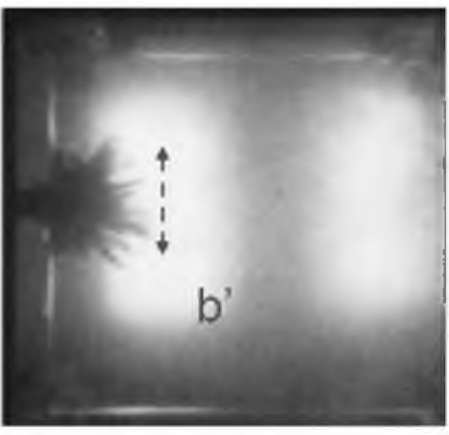

b

Fig. 14. Cracking pattern $10 \mu$ s after impact of glass by soft (a) and hard (b) bullet [9]

In another work [4], a deterministic approach for the mentioned condition loading was proposed to supersede the probabilistic one based on the obtained deterministic strength value under high loading rate. Accordingly, we conclude that the brittle materials, especially the glass material, subjected to impact condition should not be considered as a "simple" dynamic problem due to the very high sensitivity contact zone and corresponding defect activations regarding to impact and CSHPB. For these reasons, the brittle material (MBD lead glass in this paper) shows greater scatter strength value, whereas under the impact loading condition it can have less scatter strength value. It is also required to remind that the impact problem needs the deterministic approach [4]. Consequently, the application of dynamic loading on the brittle materials must be thoughtfully distinguished as the longitudinal elastic compressive wave propagation by means of CSHPB without contact zone and the same wave application with damaged contact zone by impact. Furthermore the choice between the probabilistic approach and the deterministic one must be made and it must be based upon the dynamic loading type.

Conclusions. The compressive tests on MBD lead glass specimen under quasi static and dynamic loadings have been performed. The static experimental results have been successively compared with the spherical glass specimen. According to the results the failure initiation is located at the maximum tensile zone near the small hole to which the maximum tensile stress is applied, but not at the damaged contact zone, whereas the spherical glass specimen provokes failure by activated defects on the contact zone under the static condition. Hence, the contact pressure manipulates the behavior of the brittle materials due to the high defect sensitivities on surface. The MBD lead glass specimen is broken into multi-fragmentation under CSHPB and the compressive wave has provoked the defects not on surface but volume. Therefore, the MBD lead glass specimen highlights greater strength and scatter data level compared with the static's one under dynamic loading. It is different from the results in the literature [4, 5], i.e., the activated defects located on damaged contact area via impact loading condition exhibit less scatter strength. Consequently, the contact problem has an effect on the scatter strength value under impact. Finally, the utilization of probabilistic method like Weibull's distribution is no longer valid if the materials behave under a rigorous contact problem. 


\section{Р ез}

Для різних швидкостей навантаження оцінено локалізацію активованих дефектів у скляному зразку у вигляді модифікованого бразильського диска у порівнянні зі стандартним сферичним зразком. Геометрія зразка може суттєво впливати на механічну поведінку матеріалів, особливо це стосується крихких матеріалів, які дуже чутливі до розподілу дефектів. Отримані результати аналізуються за допомогою статистичного підходу Вейбулла. Із використанням універсальної випробувальної машини "Інстрон” та захватів Гопкінсона для стиску реалізовано високі і низькі швидкості навантаження зразків у вигляді модифікованого бразильського диска 3 високоміцного скла. Отримані експериментальні дані порівнюються з розподілом Вейбулла відносно розсіяння характеристик міцності. За допомогою методу скінченних елементів розраховано поле напружень у зразках вказаного типу, що дозволило більш детально дослідити крихкий макромеханічний механізм руйнування. Установлено, що за статичних випробувань сферичних скляних зразків виникають контактні напруження, що призводить до активації дефектів у робочій частині зразка. У зразках типу модифікованого бразильського диска активація дефектів відсутня як за статичного, так і за динамічного навантаження. Для зразків, що мають різну геометричну форму і вид прикладання навантаження, рекомендується використовувати імовірнісний підхід, наприклад підхід Вейбулла, оскільки контактні напруження у крихких матеріалах призводять до активації дефектів, розподіл яких, у свою чергу, залежить від геометрії і виду навантаження зразка.

1. A. G. Griffith, "The phenomena of rupture and flow in solid," Phil. Trans. Roy. Soc. London, A221, 163-193 (1920).

2. W. Weibull, "A statistical distribution functions of wide applicability," $J$ Appl. Mech. (1951).

3. A. M. Freudenthal, in: H. Liebowitz (Ed.), Fracture, Academic Press, New York (1968), Vol. 2, p. 592.

4. F. Hild, C. Denoual, P. Forquin, and X. Barjer, "On the probabilisticdeterministic transition involved in a fragmentation process of brittle materials," Comp. Struct., 81, 1241-1254 (2003).

5. S. Bouzid, A. Nyoungue, Z. Azari, et al., "Fracture criterion for glass under impact loading," Int. J. Impact Eng., 25, 831-845 (2001).

6. Y. S. Cheng, G. K. Reynolds, A. D. Salman, and M. J. Hounslow, "Modeling fragment size distribution using two-parameter Weibull equation," Int. J. Mineral Proc., 74S, 227-237 (2004).

7. Y. S. Cheng, A. D. Salman, M. J. Hounslow, "Effect of impact angle and velocity on the fragment size distribution of glass spheres," Powder Technol., 138, 189-200 (2003).

8. S. Ho Cho, Y. Ogata, K. Kaneko, "Strain-rate dependency of the dynamic tensile strength of rock," Int. J. Rock Mech. Mining Sci., 40, 763-777 (2003). 
9. X. Brajer, P. Forquin, R. Gy, F. Hild, "The role of the surface and volume the defects in the fracture of glass under quasi-static and dynamic loadings," J. Non-Crystalline Solids, 42-53 (2003).

10. M. M. Chaudhrin, "Impact breakage of semi-brittle spheres," Powder Technol., 143-144, 31-40 (2004).

11. Y. Hiramatus and Y. Oka, in: Proc. Second Congress of International Society of Rock (1970), pp. 190-206.

12. A. Nyoungue, Comportement à la Rupture des Matériaux Fragiles sous Sollicitation Dynamiques Application sur le Verre, $\mathrm{Ph}$. D. Thesis, Université de Metz (2001).

13. X. He and S. O. Oyadiji, "Application of the coefficient of variation in reliability-based mechanical design and manufacture," J. Mater. Proc. Technol., 119, 374-378 (2001).

14. F. A. Veer, A. Van den Berg, and M. M. A. Van der Sluijs, "The strength of glass," in: ECF 14, Fracture Mechanics Beyond (2000), Vol. 3, pp. 503-510.

15. D. R. Oakley, "An empirical study of the effect of stressed area on the strength of float glass the surfaces," J. Non-Crystalline Solids, 196, 134-138 (1996).

16. J. Jeong, H. Adib, and G. Pluvinage, "Proposal of new damage model for thermal shock based on dynamic fracture on the brittle materials", $J$. NonCrystalline Solids, 351, 2065-2075 (2005).

17. L. Ninan, J. Tsai, and C. T. Sun, "Use of split Hopkinson pressure bar for testing off-axis composites," Int. J. Impact Eng., 291-313 (2001). 